\title{
Lactic Acid Bacteria from Argentinean Fermented Foods: Isolation and Characterization for their Potential Use as Starters for Fermentation of Vegetables
}

\author{
Gabriel D. Sáez ${ }^{1,2}$, Leandro \\ Flomenbaum ${ }^{1}$ and \\ Gabriela Zárate ${ }^{1,2 *}$
}

\begin{abstract}
'San Pablo Tucumán University, Av. Solano Vera and Villa Nougués, T4129XAK, Tucumán, Argentina ${ }^{2}$ Reference Centre for Lactobacilli (CERELA-CONICET), Chacabuco 145, T4000ILC San Miguel de Tucumán, Argentina
\end{abstract}

Received: 30 November 2017 Accepted: 24 April 2018

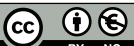

\begin{abstract}
SUMMARY
Lactic acid bacteria (LAB) improve the organoleptic, nutritional and physicochemical properties of artisanal foods. In this study, we selected 31 fermented dairy and vegetable foods marketed in Tucumán city, Argentina, as sources of LAB for the production of pickles. Sixty-four isolates presumptively identified as Lactobacillus strains were screened for relevant technological properties for production of fermented foods. Most strains showed moderate to good acidification $(>0.04 \mathrm{pH}$ units $/ \mathrm{h}$ ) and proteolytic capabilities (free aminoacids $>1 \mathrm{mmol} / \mathrm{L}$ ), produced diacetyl and/or acetoin and were resistant to $4 \% \mathrm{NaCl}$. Based on acid production and osmotolerance, we selected six LAB strains and identified them by 16S rDNA sequencing (97-100 \% identity) as: Lactobacillus rhamnosus CRL2159 and CRL2164, L. plantarum CRL2161 and CRL2162, Weissella viridescens CRL2160 and W. paramesenteroides CRL2163. Relevant properties for pickle manufacturing were further assessed. At an initial pH=4.5 and $7 \% \mathrm{NaCl}$, L. plantarum CRL2162 and L. rhamnosus CRL2164 performed the best with high growth and inhibitory activity against Escherichia coli and Listeria innocua. There was no obvious antagonism among the selected strains that would dismiss their use in mixed cultures. Properties of the selected LAB suggest their potential as starter cultures for obtaining standardized, fermented vegetable products of high quality. The development of these new industrial starters would increase the competitiveness of production and open the country's frontiers in the canned vegetable market.
\end{abstract}

Key words: fermented vegetables, lactic acid bacteria, starter culture, pickles

\section{INTRODUCTION}

Fermentation is a biological process widely used for food production and preservation. In recent decades, the fermentation technology used in food manufacturing has moved from artisanal practices to industrialized biotechnological processes that allow for the production of high quality standardized products. This change is possible because of the usage of starter cultures, which are pure or mixed cultures of microorganisms inoculated into a food matrix in order to replace its endogenous microbiota and improve the fermentation by enhancing nutritional and functional properties, organoleptic characteristics and safety (1).

The main microorganisms involved in industrial fermentations are yeasts and bacteria whose selection depends on their final metabolites. Lactic acid bacteria (LAB) are the most desirable for food manufacturing due to their technological and probiotic properties, whereas other genera, such as Propionibacterium (2) and Acetobacter (3), are used for the production of propionic and acetic acids, respectively.

When selecting $L A B$ for food fermentations, different technological properties that could be relevant for the final product must also be considered. This properties include the acidifying, proteolytic and lipolytic activities that contribute to the preservation, flavour and nutritional quality of the product. Additionally, the presence of enzymatic activities involved in the removal of antinutritional factors (ANF), and the protection of consumers from their adverse effects is a desired feature. Resistance to different stressful conditions, such as high salt concentrations, development at acidic $\mathrm{pH}$ and growth at high or low temperatures, are also considered as selection criteria for the development 
of starters for the food industry. Vegetables are an important niche for the isolation and selection of LAB for starter and probiotic applications $(4,5)$. The fermented plants most widely consumed around the world include olives, cucumbers and cabbage, and to a lesser extent carrots, beets and peppers. Eastern countries also produce fermented products that incorporate radishes, turnips, Brussels sprouts, and legumes (6).

In Argentina, canned vegetables and fermented artisanal foods such as pickles are well-accepted products consumed as an appetizer or a side dish. The manufacture of pickled vegetables involves spontaneous fermentation, leading to the dominance of lactic acid microbiota. The acid produced by these microorganisms eliminates both spoilage bacteria (mainly enterobacteria and sporulated bacteria) and their pectinolytic enzymes responsible for putrefaction. $L A B$ that dominate primary fermentation include Enterococcus faecalis, Leuconostoc mesenteroides, Lactobacillus brevis and Lactobacillus plantarum. However, the first two species do not resist high salt concentrations or acidification and rapidly decline, whereas lactobacilli complete the majority of vegetable fermentations (5). Although many fermented vegetable products are on the market in northwestern Argentina, their artisanal production without the addition of starter cultures makes them an important reservoir of autochthonous $L A B$ with the potential for further applications. The development of industrial starters for fermentation of pickles would offer products with more appreciable organoleptic properties and a longer shelf-life, and would provide an economic alternative within the food chain. This would increase the competitiveness of production, leading to the opening of new frontiers in the canned vegetable market. Therefore, the objective of this work is to isolate and select LAB strains from different artisanally fermented products for the formulation of a starter culture applicable to pickle fermentation. For this purpose, we evaluated a series of technological properties relevant for this type of fermented food production and the compatibility of the selected strains.

\section{MATERIALS AND METHODS}

\section{Isolation of lactic acid bacteria from artisanally fermented foods}

Thirty-one artisanally fermented products (pickles made from carrots, peppers, onions and cabbages; olives and cheese made with unpasteurized milk) came from different local markets in San Miguel de Tucumán city, Argentina. Samples $(10 \mathrm{~g})$ were homogenized in $90 \mathrm{~mL}$ sterile $0.9 \%(\mathrm{~m} / \mathrm{V})$ $\mathrm{NaCl}, 10$-fold diluted and plated at $37^{\circ} \mathrm{C}$ and $5 \% \mathrm{CO}_{2}$ for $72 \mathrm{~h}$ on MRS agar (composition in $\mathrm{g} / \mathrm{L}$ : meat peptone 10, beef extract 10 , yeast extract 5 , glucose 20 , sodium acetate 5 , ammonium citrate $2, \mathrm{~K}_{2} \mathrm{HPO}_{4} 2$, Tween $801, \mathrm{MgSO}_{4} \cdot 7 \mathrm{H}_{2} \mathrm{O} 0.2, \mathrm{MnSO}_{4} \cdot 4 \mathrm{H}_{2} \mathrm{O}$ 0.05, and agar 15, pH=6.5; Laboratorios Britania SA, Buenos Aires, Argentina) selective for lactic acid bacteria, and Rogosa agar (composition in $\mathrm{g} / \mathrm{L}$ : meat peptone 10, yeast extract 5 , glucose $20, \mathrm{KH}_{2} \mathrm{PO}_{4} 6$, ammonium citrate 2 , sodium acetate 1 ,
Tween 80 1, $\mathrm{MgSO}_{4} \cdot 7 \mathrm{H}_{2} \mathrm{O} 0.57, \mathrm{MnSO}_{4} \cdot 4 \mathrm{H}_{2} \mathrm{O} 0.12, \mathrm{FeSO}_{4} 0.034$ and agar, $15 \mathrm{pH}=5.4$, with glacial acetic acid; Oxoid, Basingstoke, UK) selective for lactobacilli. Colonies selected by their different morphology and texture were transferred to LAPTg broth (composition in $\mathrm{g} / \mathrm{L}$ : meat peptone 15, tryptone 10, yeast extract 10, glucose 10 and Tween 80 1, pH=6.5; Laboratorios Britania SA) and their phenotypic evaluation followed the methods of Kandler and Weiss (7). Gram-positive, catalase-negative and nitrate reductase-negative bacilli were selected for further characterization.

\section{Technological properties of isolates}

Grown cultures were standardized using a Spectronic 20 spectrophotometer (Bausch \& Lomb, Rochester, NY, USA) to absorbance $A_{560 \mathrm{~nm}}=0.8$ in phosphate-buffered saline (Laboratories $\mathrm{Cicarelli}^{\circledR}$, Santa Fe, Argentina), inoculated at $2 \%$ rate into $10 \%(\mathrm{~m} / \mathrm{V})$ reconstituted skimmed milk (La Serenísima, Buenos Aires, Argentina) and incubated at $37^{\circ} \mathrm{C}$ for $24 \mathrm{~h}$.

The acidification capacity of the microorganisms was determined by pH (Altronix TPX I pH meter; Brooklyn, NY, USA) and titratable acidity measurements at 12 and $24 \mathrm{~h}$ of incubation (8).

Proteolytic activity of isolates was determined using the spectrophotometric assay of Church et al. (9). Samples were deproteinized with $0.75 \mathrm{M}$ trichloroacetic acid (1:2) (Laboratorios $\left.\mathrm{Cicare} \mathrm{Ii}^{\circledR}\right)$ and then supernatants were incubated in an o-phthaldialdehyde (o-PA) solution $(50 \mathrm{~mL}$ of $100 \mathrm{mM}$ sodium tetraborate; Merck, Darmstadt, Germany; $5 \mathrm{~mL}$ of $20 \%$ $(\mathrm{m} / \mathrm{V})$ sodium dodecyl sulphate; Merck; $2 \mathrm{~mL}$ of $40 \mathrm{mg} / \mathrm{mL}$ o-Pa dissolved in methanol, and $0.2 \mathrm{~mL} \beta$-mercaptoethanol; Sigma-Aldrich, Merck, St. Louis, MO, USA) for $10 \mathrm{~min}$ at room temperature before reading the absorbance at $A_{340 \mathrm{~nm}}$ with a UV-visible spectrophotometer (Varian, Agilent Technologies, Santa Clara, CA, USA). The results were expressed in mmoles of free aminoacids (FAA) per litre of milk by referring to a standard curve of L-leucine. Activities were classified as low, intermediate and high (0-1, 1-2 and $>2 \mathrm{mmol} / \mathrm{L}$, respectively).

Amylolytic activity was determined by the ability of bacteria to hydrolyse starch in agar. Active LAB were streaked on LAPT agar plates containing $1 \%$ starch instead of glucose, incubated at $37^{\circ} \mathrm{C}$ for $48 \mathrm{~h}$, and then flooded with a $4 \%(\mathrm{~m} / \mathrm{V})$ iodine solution (Laboratorios Britania SA). The appearance of a clearing zone around the colonies confirmed amylase production and the diameter of these halos was measured with a calliper (10).

Medina et al. (11) assessed lipolytic activity using the tributyrin agar diffusion assay. Agar plates containing $20 \mathrm{~mL}$ medium composed of: $1.5 \%(\mathrm{~m} / \mathrm{V})$ agar-agar, $0.25 \%$ (by volume) triglycerides, $0.02 \%(\mathrm{~m} / \mathrm{V})$ sodium azide and $100 \mathrm{mmol} / \mathrm{L} \mathrm{so-}$ dium phosphate buffer, $\mathrm{pH}=7.0$ (Laboratorios Cicarelli ${ }^{\circledR}$ ) were prepared and once solidified, wells of $1 \mathrm{~cm}$ in diameter were made on the agar. Aliquots of cell suspensions $(100 \mu \mathrm{L})$ were inoculated into the wells and activity was observable as a detectable zone of hydrolysis (halos) after $48 \mathrm{~h}$ of incubation at $37^{\circ} \mathrm{C}$. 
Diacetyl and/or acetoin production was determined qualitatively from coagulated milk samples. A 1-mL aliquot was mixed with $0.5 \mathrm{~mL}$ of $0.5 \%(\mathrm{~m} / \mathrm{M})$ a-naphthol and $0.2 \mathrm{~mL} \mathrm{KOH}$ -creatine (0.3 g creatine (Sigma-Aldrich, Merck) in $40 \% \mathrm{KOH}$ Laboratorios Cicarelli ${ }^{\circledR}$ ) for $15 \mathrm{~s}$ and allowed to stand for $5 \mathrm{~min}$. The appearance of a red ring at the top of the tube represented positive result (11).

Tolerance to acid and saline stresses was evaluated by assessing the growth of microorganisms in LAPTg broth acidified with lactic acid (Sintorgan SA, Buenos Aires, Argentina) to $\mathrm{pH}=5.5,5.0,4.5$ or 4.0 , or supplemented with $2,4,7$ or $10 \%$ $(\mathrm{m} / \mathrm{V}) \mathrm{NaCl}$ (Laboratorios Cicarelli $\left.{ }^{\circledR}\right)$, respectively. Growth was determined by the increase of bacterial biomass absorbance $\left(A_{560 \mathrm{~nm}}\right)$ measured at intervals during $24 \mathrm{~h}$ of incubation at 37 ${ }^{\circ} \mathrm{C}$. The experimental data of the growth curves were adjusted using the reparameterized Gompertz model (12) expressed by the following function (13):

$$
A_{\mathrm{t}}=A_{0}+A \exp \left\{-\exp \left[(\mu \cdot e / A)\left(t_{1}-t\right)+1\right]\right\}
$$

where $A_{\mathrm{t}}$ is absorbance at time $t, t$ is time of growth in hours, $A_{0}$ is absorbance at $t=0, A$ is increase of molar absorption coefficient between $A_{0}$ and $A_{\text {max }} \mu$ is maximum growth rate $\left(\mathrm{h}^{-1}\right), t_{1}$ is duration time of lag phase in hours, and $e$ is base of Napierian logarithm (2.718281828). Calculated parameters were considered relevant within the bacterial growth dynamic as they reflect the behaviour of strains under each one of the assayed conditions.

\section{Genotypic identification of strains}

The $16 \mathrm{~S}$ ribosomal RNA gene was sequenced to identify the microorganisms. Total genomic DNA extraction followed the protocol described by Pospiech and Neumann (14). Amplification of variable region $\mathrm{V} 1$ of the $16 \mathrm{~S}$ ribosomal RNA gene was performed by polymerase chain reaction (PCR) using primers PLB16 (5' AGA GTT TGA TCC TGG CTC AG 3') and MLB16 (5' GGC TGC TGG CAC GTA GTT AG 3') (15). The amplification programme was carried out in a thermocycler (MyCicler, BIORAD, Hercules, CA, USA), and consisted of a 5-minute initial denaturation at $94^{\circ} \mathrm{C}$, followed by $30 \mathrm{cycles}$ at $94^{\circ} \mathrm{C}(30 \mathrm{~s}), 52^{\circ} \mathrm{C}(30 \mathrm{~s})$ and $72^{\circ} \mathrm{C}(45 \mathrm{~s})$, and finally an elongation step of $10 \mathrm{~min}$ at $72^{\circ} \mathrm{C}$. The amplicons obtained from the reaction were purified with PEG (20\% polyethylene glycol 8000 in $2.5 \mathrm{M} \mathrm{NaCl}$; Sigma-Aldrich, Merck) and sequenced using an ABI 3139 DNA sequencer (Applied Biosystems, Foster, CA, USA) (16). The identity of the sequences was determined by comparison with sequences deposited in online databases: BLAST GenBank and Ribosomal Database Project $(17,18)$. The sequences of the partial $16 \mathrm{~S}$ rRNA of $L A B$ were submitted to the European Nucleotide Archive database (accession numbers LT714201 to LT714206) (19).

\section{Tannase and gallate decarboxylase activities}

The presence of enzymes involved in antinutritional tannin metabolism was determined according to the method of Osawa et al. (20) with some modifications (21). For tannase (EC
3.1.1.20) activity, cultures grown on MRS agar were harvested with sterile cotton swabs and suspended up to absorbance value of $A_{560 \mathrm{~nm}}=1$ in $33 \mathrm{mmol} / \mathrm{L} \mathrm{NaH}_{2} \mathrm{PO}_{4}$ (Laboratorios Cicarelli ${ }^{\circledR}$ ) containing $20 \mathrm{mmol} / \mathrm{L}$ methylgallate (Sigma-Aldrich, Merck), $\mathrm{pH}=5$. Bacterial suspensions were incubated aerobically at 37 ${ }^{\circ} \mathrm{C}$ for $24 \mathrm{~h}$ and then alkalinized with a $2 \mathrm{M} \mathrm{NaHCO}_{3}$ solution $\left(\mathrm{pH}=8.6\right.$; Laboratorios Cicarelli $\left.{ }^{\circledR}\right)$. After exposure to air for $1 \mathrm{~h}$ at room temperature $\left(25^{\circ} \mathrm{C}\right)$, the development of a green to brown colour of the medium was considered a positive result for tannase enzyme. For gallate decarboxylase (EC 4.1.1.59) activity, overnight cultures were inoculated at $1 \%$ (by volume) in MRS broth supplemented with $10 \mathrm{mmol} / \mathrm{L}$ gallic acid (Sigma-Aldrich, Merck) and incubated anaerobically at $37^{\circ} \mathrm{C}$ for $72 \mathrm{~h}$. Cultures were then alkalinized with a $2 \mathrm{M} \mathrm{NaHCO}_{3}$ solution ( $\mathrm{pH}=8.6$ ) and incubated aerobically at $37^{\circ} \mathrm{C}$ for $1 \mathrm{~h}$. Development of a dark yellow to brown colour was taken as a positive result for gallate decarboxylase enzyme.

\section{Inhibition of pathogens}

The ability of the isolates to produce antimicrobial substances was determined using an agar well diffusion assay (21). Two common food pathogens, Escherichia coli C3 (from Institute of Microbiology “Luis Verna” of University of Tucumán, Argentina) and Listeria innocua 7 (from Unité de Recherches Laitières et Génétique Appliqué, INRA, Jouy-en-Josas, France) were used as indicator strains. Overnight cultures of LAB grown in MRS at $37^{\circ} \mathrm{C}$ were harvested by centrifugation (5000×g, 10 min at $4{ }^{\circ} \mathrm{C}$ ) in a tube centrifuge (Presvac, Buenos Aires, Argentina) and filtered through $0.22-\mu \mathrm{m}$ pore size filters (Biopore SRL, Buenos Aires, Argentina) to obtain cell-free supernatants. To elucidate the nature of antimicrobial compounds, aliquots of cell-free supernatants were adjusted to $\mathrm{pH}=6.5$ with $1 \mathrm{M} \mathrm{NaOH}$ (Laboratorios Cicarelli ${ }^{\circledR}$ ), and treated with catalase $(300 \mathrm{IU} \mathrm{mL} / \mathrm{L}$ ) or proteinase $\mathrm{K}\left(1 \mathrm{mg} / \mathrm{L}, 3 \mathrm{~h}\right.$ at $37^{\circ} \mathrm{C}$ ) (Sigma-Aldrich, Merck) in order to discriminate acid, $\mathrm{H}_{2} \mathrm{O}_{2}$ or bacteriocin inhibition. Treated and untreated cell-free extracts were inoculated $(50 \mu \mathrm{L})$ in wells made in brain heart infusion $(\mathrm{BHI})$ agar plates (Laboratorios Britania SA) seeded with each pathogen and incubated at 37 ${ }^{\circ} \mathrm{C}$ for $24 \mathrm{~h}$. The appearance of inhibition halos around each well was taken as a positive result for production of antimicrobials.

\section{Compatibility of strains}

Agar diffusion assay

Cell-free supernatants of overnight cultures of selected LAB were inoculated in wells made in LAPTg agar plates previously seeded with each of the other strains. The plates were incubated at $37^{\circ} \mathrm{C}$ for $48 \mathrm{~h}$, the presence of growth inhibitory halos was considered as an incompatibility between strains.

\section{Cross-streak assay}

Overnight cultures were washed $\left(10000 \times g, 10 \mathrm{~min}, 4^{\circ} \mathrm{C}\right)$ with sterile saline solution $(0.9 \% \mathrm{~m} / \mathrm{V} \mathrm{NaCl})$ and seeded on LAPTg agar in a straight line using a sterile swab. Cultures of 
the other strains were seeded perpendicular to the first line. After $72 \mathrm{~h}$ of incubation at $37^{\circ} \mathrm{C}$, the type of growth in the confluence zones (stimulation, inhibition, or absence of interaction between the strains) was visually determined (22).

\section{Statistical analysis}

The results are expressed as the average of three independent trials \pm standard deviation for the characterization of LAB isolates. Significant differences between mean values were determined by Tukey's test after analysis of variance (one-way ANOVA) with the Minitab v. 17 for Windows (23). A $\mathrm{p}<0.05$ was considered statistically significant. Technological properties of strains were analysed through principal component analysis using the XLSTAT software v. 19.4 (24). The Nonlinear Estimation module included in Statistica v. 13.3.0 (25) was applied to fit the growth curves and calculate growth parameters included in the Gompertz mathematical model (12).

\section{RESULTS AND DISCUSSION}

\section{Isolation and phenotypic characterization of lactic acid bacteria}

Although there is a great variety of fermented foods, most commercial LAB starter cultures are developed for the dairy industry and to a lesser extent for sausage production. Fermented vegetables are traditionally obtained through a process of spontaneous lactic acid fermentation, which is highly dependent on the epiphytic microbes present on the raw materials $(4,26)$. At present, there are few industrial starters for pickle fermentation worldwide and no autochthonous $L A B$ starter for this purpose in Argentina that could give competitive high quality products. Therefore, in the present study, we isolated and technologically characterized the endogenous lactobacilli present in 15 dairy (artisanal cheese), olives and 15 vegetable (pickles) fermented products that are marketed in the streets of San Miguel de Tucumán city located in Tucumán Province in the northwestern region of Argentina. We obtained a total of 78 isolates, and presumptively identified 64 according to phenotypic characteristics (Gram (+), catalase (-), nitrate reductase (-), bacilli) as belonging to the genus Lactobacillus, one of the most representative among $L A B$. In regards to the origin of the bacteria, similar proportions of $L A B$ isolates were obtained from both environments (53\% from dairy and $47 \%$ from pickles). To select LAB with optimal characteristics to be used as starter cultures, all of the isolates were technologically characterized concerning their relevant properties for use in fermented foods.

\section{Technological properties}

The technological properties of microorganisms from dairy and pickles are summarized in Table 1. The isolates of dairy origin displayed the best acidifying properties. A high proportion of isolates (64\%) were able to coagulate milk between 12 and $24 \mathrm{~h}$ and to decrease $\mathrm{pH}$ below 5, and they showed high acidification rates. Isolates from fermented products were divided into strains that coagulate milk between 12 and $24 \mathrm{~h}$ (50\%) and others that were unable to coagulate milk up to 36 h (50\%). Accordingly, more than $50 \%$ of the isolates showed low acidification rates. However, the percentage of strains with high acidification rates (approx. $30 \%$ ) was similar in both environments (Table 1). A rapid and high production of acid is demanded for lactic cultures to be used as starters in plant fermentation technology. Different studies have assessed the acidification activity of $\mathrm{LAB}$ from vegetables. L. plantarum $\mathrm{KJ} 03$ and $L$. fermentum KJ23 isolated from fermented stink beans (sataw-dong) reached $\mathrm{pH}=3.86-3.97$ and titratable acidity of $1.53-1.55 \%$ after $24 \mathrm{~h}$ of growth (27), whereas L. plantarum 25 and $L$. pentosus 13 isolated from pepper and beetroot pickles may be preferable as starter cultures for pickle and olive fermentations in Turkey because they produce high acid levels and most of the acid production is on the first day of fermentation (28). In our study, isolates GS25 and GS43 of dairy origin and GS31 and GS109 from olives and pickles, respectively, reached the lowest $\mathrm{pH}$ after $24 \mathrm{~h}(3.97 \pm 0.02$ to $4.03 \pm 0.02)$ and the highest acidifications rates (Table 2).

Table 1. Technological properties of Argentinian lactic acid bacteria $(\mathrm{LAB})$ isolates distributed according to their origin

\begin{tabular}{|c|c|c|}
\hline \multirow{3}{*}{ Property } & \multicolumn{2}{|c|}{$w(\mathrm{LAB}) / \%$} \\
\hline & \multicolumn{2}{|c|}{ Origin } \\
\hline & Dairy & Pickle \\
\hline \multicolumn{3}{|l|}{$t($ milk coagulation $) / \mathrm{h}$} \\
\hline$<12$ & 0 & 0 \\
\hline $12-24$ & 64 & 50 \\
\hline No coagulation up to 36 & 36 & 50 \\
\hline \multicolumn{3}{|l|}{ Final $\mathrm{pH}^{\mathrm{a}}$} \\
\hline$>6$ & 15.7 & 50 \\
\hline $5.1-6.0$ & 21 & 12.5 \\
\hline$<5.0$ & 63 & 37.5 \\
\hline \multicolumn{3}{|l|}{ Acidification rate $^{b}$} \\
\hline Low (0-0.04) & 26.3 & 57 \\
\hline Medium (0.04-0.08) & 42.1 & 14 \\
\hline $\operatorname{High}(>0.08)$ & 31.6 & 29 \\
\hline \multicolumn{3}{|l|}{ Proteolytic activityc } \\
\hline Low $(0-1)$ & 23 & 50 \\
\hline Medium (1-2) & 18 & 50 \\
\hline $\operatorname{High}(>2)$ & 59 & 0 \\
\hline \multicolumn{3}{|c|}{ Diacetyl or acetoin production } \\
\hline No production & 27 & 54 \\
\hline Low & 29 & 23 \\
\hline Medium & 32 & 23 \\
\hline High & 12 & 0 \\
\hline \multicolumn{3}{|l|}{$\begin{array}{l}\text { Osmotolerance }^{d} \\
w(\mathrm{NaCl})=2 \%\end{array}$} \\
\hline Low $\left(<50 \% A_{\text {control }}\right)$ & 6 & 17 \\
\hline $\begin{array}{l}\text { High }\left(>50 \% A_{\text {control }}\right) \\
w(\mathrm{NaCl})=4 \%\end{array}$ & 94 & 83 \\
\hline Low $\left(<50 \% A_{\text {control }}\right)$ & 68 & 90 \\
\hline $\operatorname{High}\left(>50 \% A_{\text {control }}\right)$ & 32 & 10 \\
\hline
\end{tabular}

${ }^{a}$ Final $\mathrm{pH}$ measured at coagulation time, ${ }^{\mathrm{b}}$ acidification rate expressed as $\Delta \mathrm{pH} / \mathrm{h}, \Delta \mathrm{pH}=\mathrm{pH}_{\text {initial }}-\mathrm{pH}_{\text {final, }}{ }^{\text {' }}$ proteolytic activity, expressed as mmol of free amino acids per litre of milk, dgrowth expressed as percentage of $A_{\text {control }}$ in media without $\mathrm{NaCl}$ 


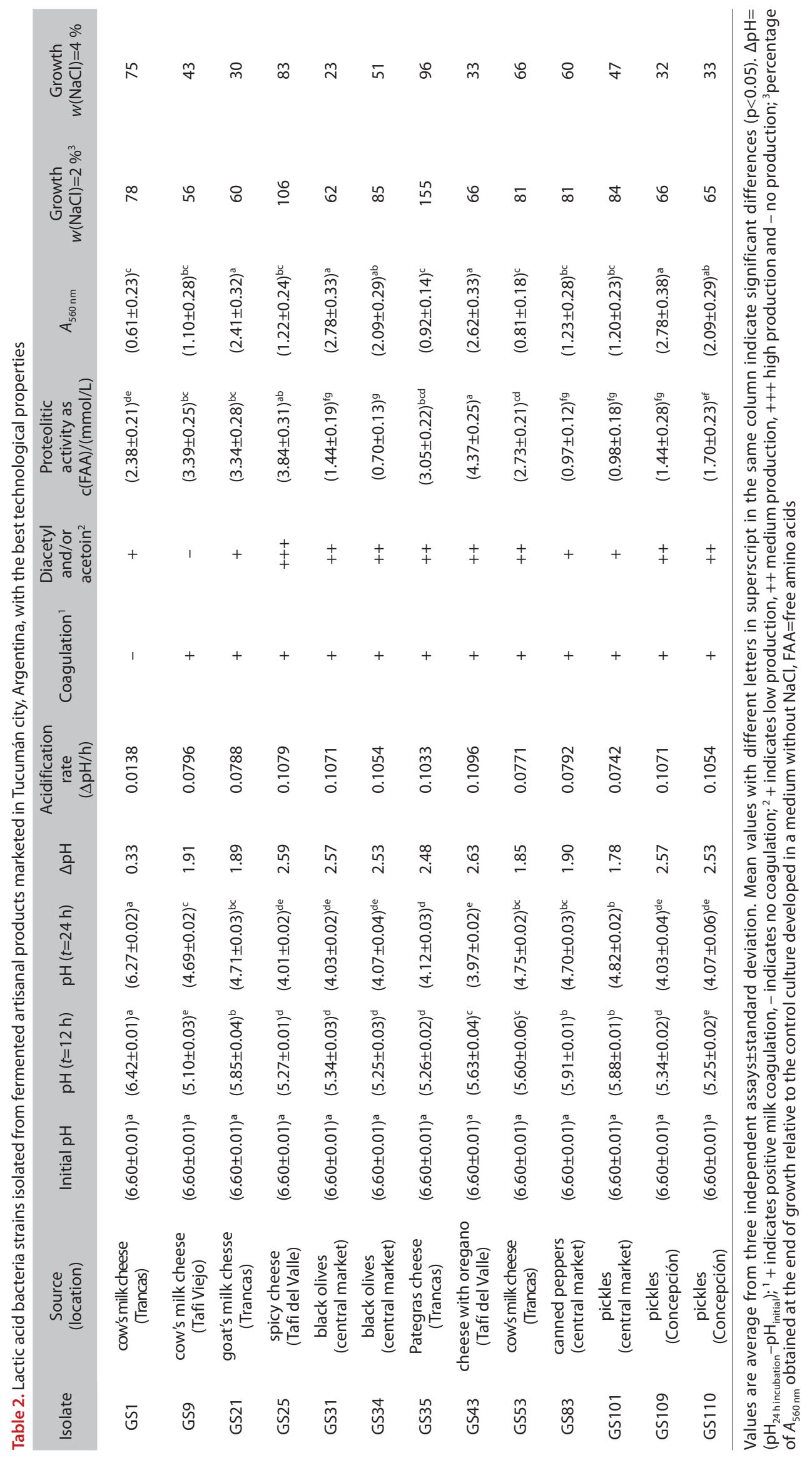


Some enzyme activities play a key role in fermentation through the release of flavour and bioactive compounds from carbohydrates, lipids and proteins. None of the strains isolated in this study showed amylolytic or lipolytic activities (data not shown), whereas proteolytic activities as FAA varied widely among isolates from $(0.70 \pm 0.13)$ to $(4.37 \pm 0.25) \mathrm{mmol} / \mathrm{L}$. Almost $60 \%$ of dairy isolates showed high proteolytic activities (FAA more than $2 \mathrm{mmol} / \mathrm{L}$ ) whereas all strains from fermented plants displayed low (FAA less than $1 \mathrm{mmol} / \mathrm{L}$ ) or intermediate activities (FAA 1 to $2 \mathrm{mmol} / \mathrm{L}$ ). This distribution could be considered expected taking into account the nature of the food matrices from which both groups of microorganisms were isolated. Milk contains casein as the main protein source and only LAB with efficient proteolytic systems (cell wall proteases and different peptidases) will be able to grow. In contrast, vegetables commonly used for pickles contain low protein and high mineral and vitamin contents. As in our study, other studies have assessed the proteolytic activities of vegetable LAB to select starter cultures for legume sourdough $(21,29)$ and pickled vegetables $(30)$.

From an industrial point of view, both the acidification capacity and proteolytic activity are preferable features of $L A B$ since they contribute to organoleptic properties and preservation of fermented foods. Additionally, the proteolytic/ peptidolytic enzymes of $L A B$ may be involved in the degradation of allergenic and antinutritional proteins and the release of bioactive peptides that are thought to promote health beyond basic nutrition (30). In the dairy industry, acidification activity is indicative of the quality of the LAB starters, but their proteolytic systems play a key role enabling their growth in milk and ensuring a successful fermentation. In addition, proteolytic enzymes release from casein the peptides and amino acids which are involved in the formation of the aroma, texture and flavour of the end product. Regarding fermented plants, the relevance of the acidifying or proteolytic abilities of $L A B$ depends on the nature of the food matrix. For fermented pickles, highly acidifying strains will contribute to the sensory quality and safety of the product, whereas fermented cereals and legumes will require highly proteolytic $L A B$ to allow for their own development, elimination of antinutritional factors, and the increase of protein digestibility. Although the isolates of our study varied in their acidification and proteolytic capacities, the dairy LAB were best adapted to milk environments, since most of them acidified and coagulated milk faster and produced more FAA than strains from fermented plants. Isolates GS25 and GS43 were the most proteolytic and released $(3.84 \pm 0.31)$ and $(4.37 \pm 0.25) \mathrm{mmol} / \mathrm{L}$ of FAA, respectively.

Regarding diacetyl and/or acetoin production, $73 \%$ of dairy isolates ( 25 out of 34 strains) were able to produce different amounts of these flavour compounds, whereas $46 \%$ of $L A B$ (14 out of 30 ) isolated from fermented plants had this property (Table 1).
Osmotolerance is another important technological property of strains intended for starter cultures of pickled vegetables since $\mathrm{NaCl}$ is a key additive in the manufacturing of this kind of food. In the presence of $2 \% \mathrm{NaCl}$ most of the isolates (44 out of 64 ) were able to reach more than $60 \%$ of the final biomass obtained in the absence of salt. Some isolates of dairy origin, such as GS25 and GS35 grew even more than the control (106 and $155 \%$ respectively), while GS34 and GS101, among the plant isolates, reached a biomass close to $85 \%$ of their respective control (Table 2). When culture media contained $4 \% \mathrm{NaCl}$, and 32 or $10 \%$ of dairy and plant $L A B$, respectively, the growth exceeded $50 \%$ of control biomass (Table 1). The ability to develop under increasing salt mass fractions has served as a selection criterion in different studies. LAB from fermented stink beans were strongly affected by $\mathrm{NaCl}$ mass fractions higher than $5 \%$, while most L. plantarum isolated from fermented vegetables in Turkey were able to tolerate $8 \% \mathrm{NaCl}(27,30)$. In the present study, dairy isolates GS25 and GS35 were the most tolerant to $4 \%$ $\mathrm{NaCl}$ ( 83 and $96 \%$ of control biomass), while GS34 and GS83 were the only isolates of plant origin that reached 51 and 60 $\%$ of control biomass.

Although strains could be selected by their individual technological features, the presence of various properties concurrently would be more appropriate for the design and development of foods with better sensory properties. Therefore, a principal component analysis (PCA) based on the technological property data of all LAB isolates, regardless of their origin, was performed in order to find the isolates with the best features for the manufacture of fermented vegetables. The estimated parameters analysed by means of PCA revealed two eigenvalues higher than 1 and the first two principal components (PCs) explaining $73.66 \%$ of the total variation, with the first discriminant function (PC1) as the most important, accounting for $52.36 \%$ of the explained variance, while the second function (PC2) explained $21.30 \%$. Fig. 1 represents the variables and observations projected in the space of PC1 and $P C 2$. Plotting data in a space defined in this way provides a rapid means of visualizing similarities or differences in a data set, allowing improved discrimination among samples or individuals. The study of the contribution of variables to factors, as well as the squared cosines of the variables, showed that factor 1 described mainly acidification capacity of the strains, whereas factor 2 described mainly tolerance to 2 and $4 \% \mathrm{NaCl}$. Osmotolerance variables had a low correlation with acidification properties. The homogenous dispersion of the isolates over the four quadrants evidenced a wide variability in the analysed variables, and the heterogeneity of LAB populations associated with these regional fermented products. The biplot graph led to the identification of a defined group of six LAB that presented simultaneously the best technological properties. This group underwent further identification and characterization. 
Biplot (axes F1 and F2: 73,66 \%)

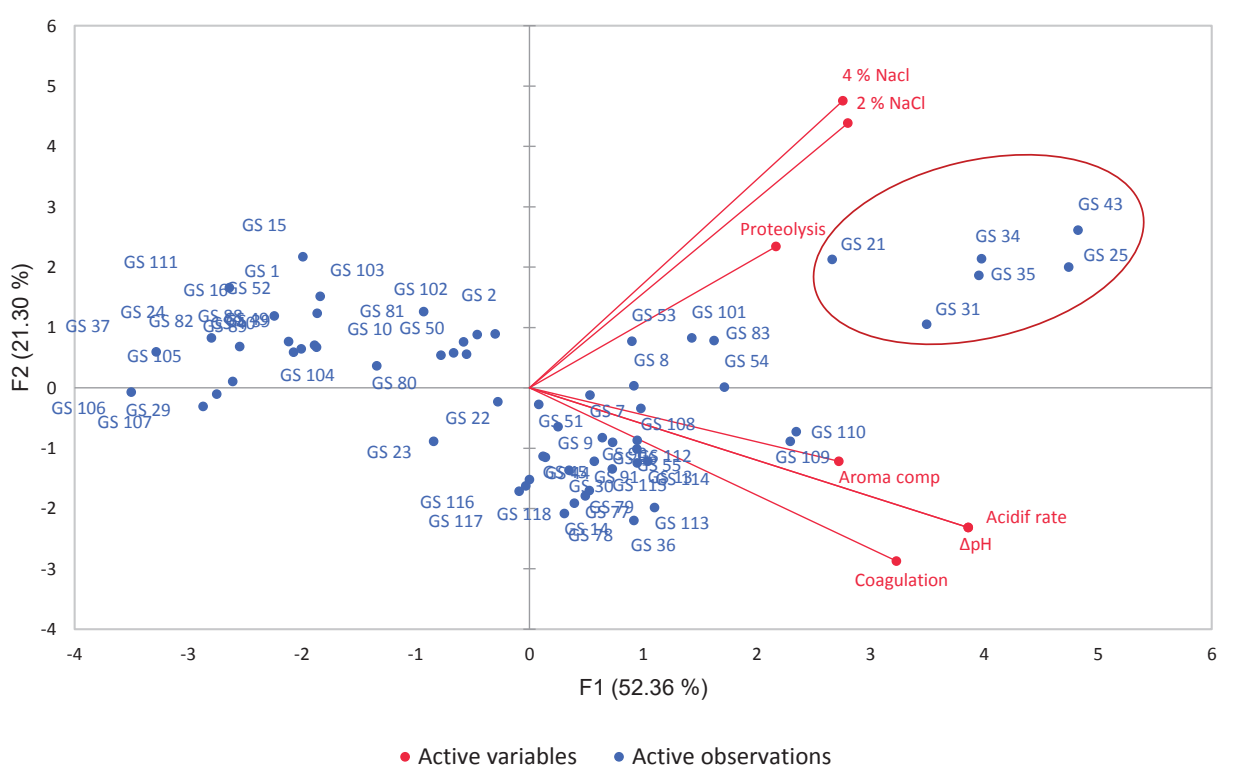

Fig. 1. Biplot graph of principal component analysis (24) performed with technological parameters of lactic acid bacteria isolates from fermented artisanal products of Tucuman city, Argentina. The six isolates showing the best parameters are enclosed in the circle

\section{Genotypic identification of selected $L A B$}

Selected LAB isolates GS31 and GS34 (isolated from pickles and olives) and GS21, GS25, GS35 and GS43 (obtained from artisanal cheese) were taxonomically identified by comparing their 16S rRNA gene sequences with sequences present in the GenBank (17) database and the cured database Ribosomal Database Project (18). Strains GS21 and GS43 showed $99 \%$ identity with Lactobacillus rhamnosus species, whereas strains GS31 and GS34 were 98 and $97 \%$ identical, respectively, to Lactobacillus plantarum. Finally, isolates GS25 and GS35 were identified as Weissella viridicens (100\% identity) and Weissella paramesenteroides ( $99 \%$ identity) respectively. The strains were deposited in the Microbial Culture Collection of CERELA, Tucumán, Argentina (affiliated to the World Federation for Culture Collections) and renamed with the code numbers provided by the Collection (Table 3 ).

Other studies have reported the presence of the same species of non-starter LAB on spontaneously fermented food of different origins and natures. L. plantarum occurs with high frequency in different fermented vegetables around the world such as brined olives $(28,31)$, sauerkraut (32), and pickles $(4,5,26,30)$. L. rhamnosus niches are more diverse, with probiotic strains originating from the human intestine (33) and other relevant isolates obtained from cheese ripening (34). Weissella strains have been isolated on the surface of fruits, beans, fermented vegetables and juices, and in some dairy products $(21,32,35)$.

\section{Tannase and gallate decarboxylase activities of selected $L A B$}

In addition to metabolic activities relevant for the organoleptic properties of the product, other features, such as the presence of enzymes involved in the removal of ANF present in the food matrix and/or the generation of bioactive metabolites could be relevant for the selection of strains as starter cultures. Vegetable tannins, present in large quantities in many plants used as food and feed, are considered nutritionally undesirable since they inhibit digestive enzymes and affect the utilization

Table 3. Identification by 16S rRNA gene sequence of lactic acid bacteria selected based on the presence of enzymes involved in antinutritional factors, reduction/bioactive compound generation and pathogen inhibition

\begin{tabular}{|c|c|c|c|c|c|c|c|c|c|}
\hline \multirow[t]{2}{*}{ Isolate } & \multirow[t]{2}{*}{ Closest relative } & \multirow[t]{2}{*}{ Identity/\% } & \multirow[t]{2}{*}{ CRL code } & \multirow{2}{*}{$\begin{array}{l}\text { Accession } \\
\text { number }\end{array}$} & \multirow[t]{2}{*}{ Tannase } & \multirow{2}{*}{$\begin{array}{c}\text { Gallate } \\
\text { decarboxylase }\end{array}$} & \multicolumn{2}{|c|}{$\begin{array}{c}\text { Pathogen inhibition by } \\
\text { cell-free supernatant }\end{array}$} & \multirow{2}{*}{$\begin{array}{l}\text { BLIS } \\
\text { production }\end{array}$} \\
\hline & & & & & & & E. coli & L.innocua & \\
\hline GS21 & Lactobacillus rhamnosus & 99 & 2159 & LT714201 & - & - & + & - & - \\
\hline GS25 & Weissella viridescens & 100 & 2160 & LT714202 & - & - & + & - & - \\
\hline GS31 & Lactobacillus plantarum & 98 & 2161 & LT714203 & + & + & + & + & - \\
\hline GS34 & Lactobacillus plantarum & 97 & 2162 & LT714204 & + & + & + & + & - \\
\hline GS35 & Weissella paramesenteroides & 99 & 2163 & LT714205 & - & + & + & - & - \\
\hline GS43 & Lactobacillus rhamnosus & 99 & 2164 & LT714206 & - & - & + & + & - \\
\hline
\end{tabular}

BLIS=bacteriocin-like inhibitory substance 
of vitamins and minerals. Tannase releases gallic acid from hydrolysable tannins whereas gallate decarboxylase decarboxylates gallic acid to pyrogallol (36). Both enzymes could be relevant for the removal of tannins and the release of bioactive phenolic compounds. In the present study, both Lactobacillus plantarum CRL2161 and CRL2162 were positive for tannase and gallate decarboxylase activities, whereas Weissella paramesenteroides CRL2163 displayed only gallate decarboxylase activity (Table 3). The presence of these enzymes has been reported previously in strains of L. plantarum (36) and other LAB species such as L. pentosus and L. paraplantarum (20). Our group has recently identified gallate decarboxylase activity in Weissella species (21). Description of degradation of complex hydrolysable tannins and phenolic acids such as gallic acid by L. plantarum, L. brevis, as well as by other microbes from herbivore guts such as Enterococcus faecalis and Streptococcus gallolyticus among others are available (37-40).

\section{Growth of selected $L A B$ under saline and acidic conditions}

The submergence of vegetables in brine with or without the addition of vinegar represents the most characteristic step of pickle manufacturing. The purpose of the addition of $\mathrm{NaCl}$ is to enhance flavour and to prevent the growth of harmful microorganisms. Since vegetables remain exposed to saline throughout the shelf life of the product, the ability of bacteria to grow and remain viable in this environment is highly desirable. Therefore, we assessed the ability of selected LAB to grow under increasing concentrations of $\mathrm{NaCl}$. The kinetics of growth determined by absorbance and growth parameters obtained by applying the Gompertz model are presented in Fig. 2 and Table 4, respectively. As a general observation, the experimental data of the growth of each LAB under the different conditions assayed showed a high goodness of fit to the model $\left(R^{2} \geq 0.97\right)$, in agreement with other studies $(12,41)$. Regarding growth parameters, as was expected, increasing the $\mathrm{NaCl}$ concentration had a negative effect on the growth of all strains, with subsequent decreases in maximum growth rates $(\mu)$ and maximum absorbance $(A)$ reached at the end of incubation, and increases of lag phase duration $\left(t_{1}\right)$ and generation time $\left(t_{\mathrm{g}}\right)$.

a)

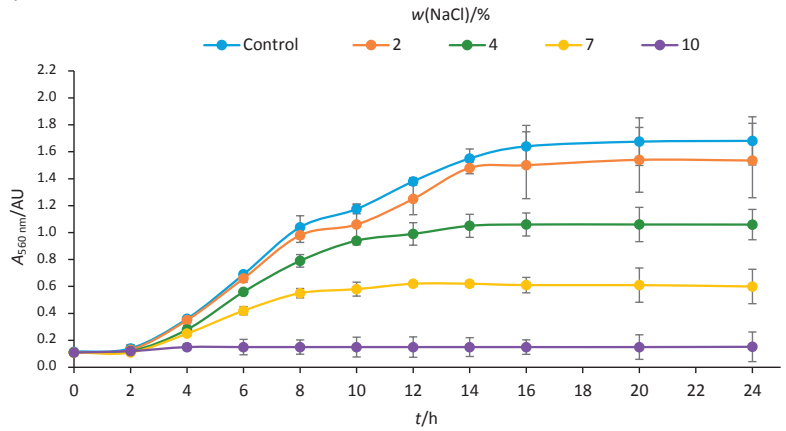

At $2 \% \mathrm{NaCl}$, all strains were able to reach more than $70 \%$ of control biomass without salt, whereas when grown in $4 \%$ $\mathrm{NaCl}$, only four strains attained more than $50 \%$ of the control growth. Strains L. plantarum CRL2162 and L. rhamnosus CRL2164 showed better growth parameters than the other selected strains ( $A=0.989$ and $0.982, \mu=0.105$ and $0.107 \mathrm{~h}^{-1}$, and $t_{\mathrm{g}}=2.857$ and $2.794 \mathrm{~h}$, respectively) (Table 4). When the $\mathrm{NaCl}$ mass fraction in the medium was $7 \%$, W. viridescens CRL2160 and L. plantarum CRL2161 reached less than $10 \%$ of control growth, while the rest of the LAB were able to reach up to $30 \%$ of their control biomass. Finally, at the highest salt mass fraction assayed ( $10 \% \mathrm{NaCl}$ ) none of the tested strains was able to grow. The observed behaviour was better than that reported by Pundir et al. (42), who determined that their vegetable-derived strains could grow in up to $6.5 \% \mathrm{NaCl}$; however, that was worse than the performance of $L$. plantarum strains isolated from fermented vegetables in Turkey that were able to tolerate $9 \% \mathrm{NaCl}(30)$.

In the same manner, proliferation of LAB under acidic conditions represents a valuable feature as it contributes to acidity and biopreservation of the product, and prolongs their ability to provide desirable characteristics to the product and/or benefits to the consumer. Fig. 3 and Table 5 show growth curves and parameters obtained by Gompertz model (12). As observed with osmotolerance, the increase in acidity of the growth media negatively affected growth parameters in most cases. At pH=5.5, L. rhamnosus CRL2164 showed better parameters than those observed in the control culture at $\mathrm{pH}=7\left(A=2.793, \mu=0.206 \mathrm{~h}^{-1}, t_{\mathrm{g}}=2.202 \mathrm{~h}\right.$ vs $A=2.114, \mu=0.136 \mathrm{~h}^{-1}, t_{\mathrm{g}}=2.202 \mathrm{~h}$ ), whereas L. plantarum CRL2162 showed similar growth to its respective control culture. At lower $\mathrm{pH}$ values (5.0 to 4.0), these two strains were also the best adapted to stressful conditions (in agreement with osmotolerance), since their growth behaviour was less affected than the other selected LAB. Weissella strains (CRL2160 and CRL2163) were the most sensitive to acid and were unable to grow at $\mathrm{pH}=4.0$.

Yu et al. (4) characterized the lactic microbiota present in Chinese pickles and observed that all isolates identified as $L$. alimentarius and L. plantarum were able to develop at $\mathrm{pH}=4.0$ and 4.5 , and in 6.0 and $6.5 \% \mathrm{NaCl}$, supporting the frequent selection of these species as starter cultures for this type of fermented food.

b)

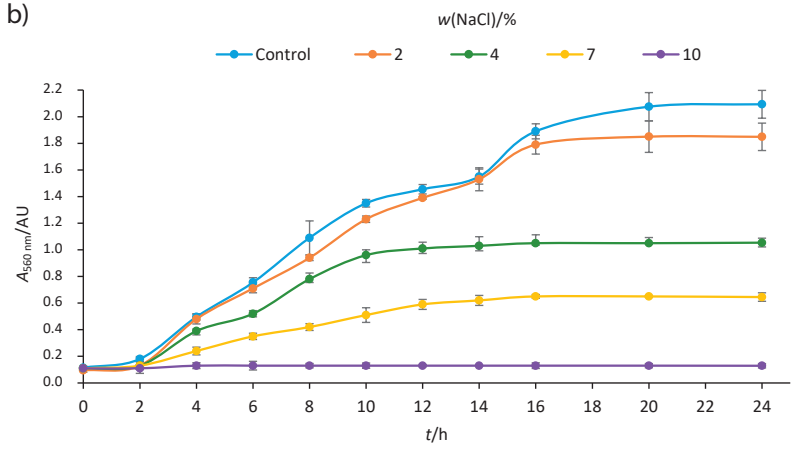

Fig. 2. Growth kinetics of most osmotolerant lactic acid bacteria developed in LAPTg broth containing 2, 4, 7 and $10 \%$ NaCl. Absorbance measured at $560 \mathrm{~nm}$ determined the biomass after $24 \mathrm{~h}$ of incubation at $37^{\circ} \mathrm{C}$. Panel: a) L. plantarum CRL2162, and b) L. rhamnosus CRL2164. Results are the mean value of three independent trials \pm standard deviation 
Table 4. Growth parameters of selected lactic acid bacteria at different NaCl mass fractions estimated with mathematical model of Gompertz (12)

\begin{tabular}{|c|c|c|c|c|c|c|}
\hline \multirow{2}{*}{ Strain } & \multirow{2}{*}{ Parameter } & \multirow{2}{*}{ Control } & \multicolumn{4}{|c|}{$w(\mathrm{NaCl}) / \%$} \\
\hline & & & 2 & 4 & 7 & 10 \\
\hline \multirow{6}{*}{ CRL2159 } & $A$ & 2.026 & 1.422 & 0.586 & 0.514 & 0.098 \\
\hline & $\mu / \mathrm{h}^{-1}$ & 0.170 & 0.108 & 0.074 & 0.064 & 0.016 \\
\hline & $t_{1} / \mathrm{h}$ & 2.63 & 1.574 & 1.701 & 2.644 & 0.283 \\
\hline & $t_{\mathrm{g}} / \mathrm{h}$ & 1.773 & 2.772 & 4.046 & 4.681 & 18.684 \\
\hline & $R$ & 0,991 & 0.997 & 0.998 & 0.997 & 0.975 \\
\hline & $v / \%$ & 98 & 99 & 98 & 99 & 95 \\
\hline \multirow{6}{*}{ CRL2160 } & $A$ & 0.789 & 0.796 & 0.708 & \multirow{6}{*}{-} & \multirow{6}{*}{-} \\
\hline & $\mu / \mathrm{h}^{-1}$ & 0.061 & 0.059 & 0.054 & & \\
\hline & $t_{1} / \mathrm{h}$ & 0.131 & 0.769 & 0.791 & & \\
\hline & $t_{\mathrm{g}} / \mathrm{h}$ & 4.930 & 5.071 & 5.480 & & \\
\hline & $R$ & 0.991 & 0.994 & 0.990 & & \\
\hline & $v / \%$ & 98 & 98 & 98 & & \\
\hline \multirow{6}{*}{ CRL2161 } & $A$ & 2.021 & 1.796 & 0.645 & \multirow{6}{*}{-} & \multirow{6}{*}{-} \\
\hline & $\mu / \mathrm{h}^{-1}$ & 0.152 & 0.130 & 0.073 & & \\
\hline & $t_{1} / \mathrm{h}$ & 1.865 & 1.742 & 0.871 & & \\
\hline & $t_{g} / \mathrm{h}$ & 1.974 & 2.304 & 4.085 & & \\
\hline & $R$ & 0.997 & 0.993 & 0.997 & & \\
\hline & $v / \%$ & 99 & 98 & 99 & & \\
\hline \multirow{6}{*}{ CRL2162 } & $A$ & 1.655 & 1.511 & 0.989 & 0.518 & \multirow{6}{*}{-} \\
\hline & $\mu / \mathrm{h}^{-1}$ & 0.132 & 0.121 & 0.105 & 0.084 & \\
\hline & $t_{1} / \mathrm{h}$ & 1.108 & 1.014 & 1.100 & 1.969 & \\
\hline & $t_{g} / h$ & 2.268 & 2.485 & 2.857 & 3.556 & \\
\hline & $R$ & 0.996 & 0.994 & 0.996 & 0.996 & \\
\hline & $v / \%$ & 99 & 98 & 99 & 99 & \\
\hline \multirow{6}{*}{ CRL2163 } & $A$ & 0.638 & 0.494 & 0.449 & 0.162 & \multirow{6}{*}{-} \\
\hline & $\mu / \mathrm{h}^{-1}$ & 0.059 & 0.058 & 0.044 & 0.024 & \\
\hline & $t_{1} / \mathrm{h}$ & 0.680 & 0.381 & 1.687 & 0.370 & \\
\hline & $t_{g} / h$ & 5.099 & 5.160 & 6.816 & 12.096 & \\
\hline & $R$ & 0.999 & 0.995 & 0.996 & 0.998 & \\
\hline & $v / \%$ & 98 & 99 & 99 & 99 & \\
\hline \multirow{6}{*}{ CRL2164 } & $A$ & 2.114 & 1.861 & 0.982 & 0.570 & \multirow{6}{*}{-} \\
\hline & $\mu / \mathrm{h}^{-1}$ & 0.136 & 0.133 & 0.107 & 0.051 & \\
\hline & $t_{1} / \mathrm{h}$ & 1.174 & 1.406 & 1.312 & 1.226 & \\
\hline & $t_{g} / \mathrm{h}$ & 2.202 & 2.260 & 2.794 & 5.812 & \\
\hline & $R$ & 0.995 & 0.997 & 0.993 & 0.997 & \\
\hline & $v / \%$ & 99 & 99 & 98 & 99 & \\
\hline
\end{tabular}

$A=$ increase of absorbance between $A_{0}$ and $A_{\max } \mu=$ maximum growth rate, $t_{1}=$ duration time of lag phase, $t_{\mathrm{g}}=$ generation time (doubling time of the bacterial population), $R=$ Pearson's coefficient of determination, $v=$ coefficient of correlation, - indicates no growth of the microorganism

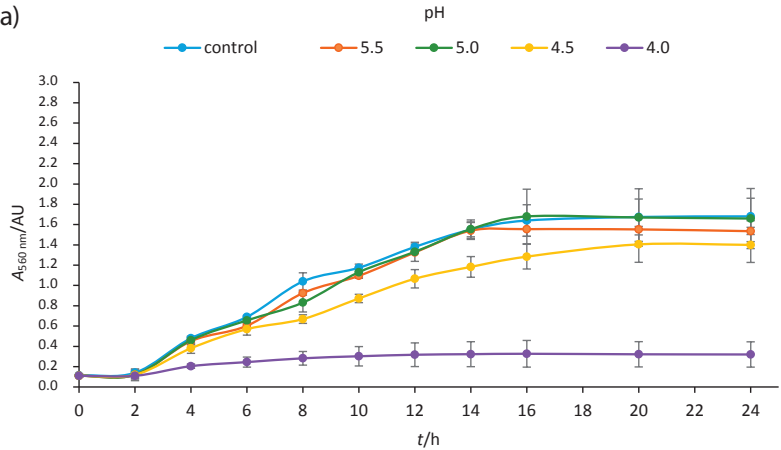

b)

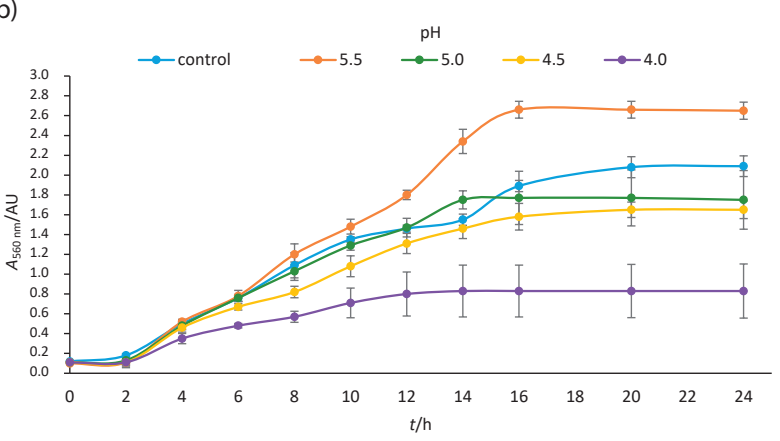

Fig. 3. Growth kinetics of most osmotolerant lactic acid bacteria developed in LAPTg broth adjusted to $\mathrm{pH}=4.0,4.5,5.0$ and 5.5. Absorbance measured at $560 \mathrm{~nm}$ determined the biomass after $24 \mathrm{~h}$ of incubation at $37^{\circ} \mathrm{C}$. Panel: a) L. plantarum CRL2162, and b) L. rhamnosus CRL2164. Results are the mean value of three independent trials \pm standard deviation 
Table 5. Growth parameters of selected lactic acid bacteria at different pH estimated with mathematical model of Gompertz (12)

\begin{tabular}{|c|c|c|c|c|c|c|}
\hline \multirow{2}{*}{ Strain } & \multirow{2}{*}{ Parameter } & \multirow{2}{*}{ Control } & \multicolumn{4}{|c|}{$\mathrm{pH}$} \\
\hline & & & 5.5 & 5.0 & 4.5 & 4.0 \\
\hline \multirow[t]{6}{*}{ CRL2159 } & $A$ & 2.026 & 1.677 & 1.814 & 1.353 & 0.512 \\
\hline & $\mu / \mathrm{h}^{-1}$ & 0.170 & 0.111 & 0.103 & 0.094 & 0.046 \\
\hline & $t_{1} / \mathrm{h}$ & 2.63 & 2.405 & 2.223 & 3.737 & 0.960 \\
\hline & $t_{g} / \mathrm{h}$ & 1.773 & 2.703 & 2.914 & 3.194 & 6.489 \\
\hline & $R$ & 0,991 & 0.997 & 0.993 & 0.983 & 0.995 \\
\hline & $v / \%$ & 98 & 99 & 98 & 96 & 99 \\
\hline \multirow[t]{6}{*}{ CRL2160 } & $A$ & 0.789 & 0.757 & 0.521 & & \\
\hline & $\mu / \mathrm{h}^{-1}$ & 0.061 & 0.060 & 0.032 & & \\
\hline & $t_{1} / \mathrm{h}$ & 0.131 & 1.138 & 1.431 & - & - \\
\hline & $t_{g} / \mathrm{h}$ & 4.930 & 4.982 & 9.348 & & \\
\hline & $R$ & 0.991 & 0.995 & 0.996 & & \\
\hline & $v / \%$ & 98 & 99 & 99 & & \\
\hline \multirow[t]{6}{*}{ CRL2161 } & $A$ & 2.021 & 1.635 & 1.242 & 1.274 & 0.644 \\
\hline & $\mu / \mathrm{h}^{-1}$ & 0.152 & 0.125 & 0.108 & 0.097 & 0.057 \\
\hline & $t_{1} / \mathrm{h}$ & 1.865 & 1.985 & 2.069 & 2.236 & 1.789 \\
\hline & $t_{\mathrm{g}} / \mathrm{h}$ & 1.974 & 2.392 & 2.764 & 3.095 & 5.228 \\
\hline & $R$ & 0.997 & 0.993 & 0.998 & 0.999 & 0.995 \\
\hline & $v / \%$ & 99 & 98 & 99 & 99 & 99 \\
\hline \multirow[t]{6}{*}{ CRL2162 } & $A$ & 1.655 & 1.535 & 1.686 & 1.405 & 0.226 \\
\hline & $\mu / \mathrm{h}^{-1}$ & 0.132 & 0.132 & 0.128 & 0.092 & 0.027 \\
\hline & $t_{1} / \mathrm{h}$ & 1.108 & 1.593 & 1.507 & 1.184 & 0.275 \\
\hline & $t_{g} / \mathrm{h}$ & 2.268 & 2.277 & 2.347 & 3.262 & 10.944 \\
\hline & $R$ & 0.996 & 0.992 & 0.993 & 0.997 & 0.998 \\
\hline & $v / \%$ & 99 & 98 & 99 & 99 & 99 \\
\hline \multirow[t]{6}{*}{ CRL2163 } & $A$ & 0.638 & 0.705 & 0.554 & 0.377 & \\
\hline & $\mu / \mathrm{h}^{-1}$ & 0.059 & 0.057 & 0.046 & 0.026 & \\
\hline & $t_{1} / \mathrm{h}$ & 0.680 & 0.818 & 1.751 & 0.743 & - \\
\hline & $t_{\mathrm{g}} / \mathrm{h}$ & 5.099 & 5.193 & 6.500 & 11.489 & \\
\hline & $R$ & 0.999 & 0.993 & 0.997 & 0.998 & \\
\hline & $v / \%$ & 98 & 98 & 99 & 99 & \\
\hline \multirow[t]{6}{*}{ CRL2164 } & $A$ & 2.114 & 2.793 & 1.749 & 1.653 & 0.754 \\
\hline & $\mu / \mathrm{h}^{-1}$ & 0.136 & 0.206 & 0.155 & 0.119 & 0.074 \\
\hline & $t_{1} / \mathrm{h}$ & 1.174 & 2.669 & 1.690 & 1.298 & 0.769 \\
\hline & $t_{\mathrm{g}} / \mathrm{h}$ & 2.202 & 1.458 & 1.933 & 2.523 & 4.029 \\
\hline & $R$ & 0.995 & 0.992 & 0.995 & 0.996 & 0.996 \\
\hline & $v / \%$ & 99 & 98 & 99 & 99 & 99 \\
\hline
\end{tabular}

$A=$ increase of absorbance between $A_{0}$ and $A_{\text {max }} \mu=$ maximum growth rate, $t_{1} / \mathrm{h}=$ duration time of lag phase, $t_{\mathrm{g}}=\mathrm{generation}$ time (doubling time of the bacterial population), $R=$ Pearson's coefficient of determination, $v=$ coefficient of correlation, - indicates no growth of the microorganism

\section{Antimicrobial activity of selected $L A B$}

Uncontrolled spontaneous vegetable fermentations are frequently sensitive to contamination from spoilage and pathogenic microorganisms, which may represent a risk to public health. It is well-known that LAB produce several antimicrobials (organic acids, $\mathrm{H}_{2} \mathrm{O}_{2}$, ethanol and bacteriocins), which can be used in food processing as alternative to chemical preservatives (43). In the present study, the ability of the selected strains to inhibit the growth of Escherichia coli and Listeria innocua, two foodborne species strongly related to the consumption of vegetable foods, was assessed as a safety property. Non-neutralized supernatants of all strains inhibited growth of $E$. coli, whereas only three of them (L. plantarum CRL2161, CRL2162 and L. rhamnosus CRL2164) were able to inhibit Listeria innocua (Table 3). When testing neutralized supernatants, there was no antagonistic activity of any $L A B$ against the two assayed pathogens, suggesting the absence of other inhibitory substances such as $\mathrm{H}_{2} \mathrm{O}_{2}$ or bacteriocins besides organic acids.

Other studies have demonstrated the ability of L. plantarum and other lactobacilli from fermented vegetables to inhibit foodborne pathogens. Çon and Karasu (28) observed that all strains of $L$. plantarum isolated from olives and pickles from western Turkey were able to inhibit $L$. monocytogenes and $E$. coli by lowering the $\mathrm{pH}$, and to a lesser extent other pathogens. Rao et al. (44) found that L. plantarum E11, isolated from Chinese pickles from the fifth day of pickling 
fermentation, produced a bacteriocin-like substance that inhibited E. coli, L. monocytogenes and Staphylococcus aureus, prolonging the safety and shelf life of this food.

\section{Compatibility of strains}

Starter cultures may consist of a single strain (monostrain) or several strains (multistrain) of the same or different species, which are combined to look for a synergism in the fermentation process (45). When evaluating potential multistrain starter cultures, it is important to carry out compatibility tests in order to avoid the combining of strains showing inhibitory activity against each other, either through the production of inhibitory substances, competition for nutrients or intercellular interactions (22). In the present study, the compatibility of different $L A B$ was determined by inhibition of growth with an agar diffusion assay and a cross-streak assay. The first method served to assess the production of antagonistic substances, whereas the second method assessed inhibition by direct interaction of microorganisms grown on the surface of an agar medium.

No inhibition halos of selected LAB cell-free supernatants against the other strains was observable, suggesting the absence of antimicrobial substances that could inhibit the development of strains combined in mixed cultures. The cross-streak assay showed similar results, as no evident competition was noticiable at sites of co-growth in solid medium in any combination of $L A B$ assayed, allowing their potential use as a multistrain starter (results not shown).

\section{CONCLUSIONS}

In the current study we isolated, technologically characterized and selected $L A B$ for the development of autochthonous starter cultures for the pickling industry. Six LAB isolates belonging to the Lactobacillus plantarum, L. rhamnosus, Weissella paramesenteroides and $W$. viridicens species showed promising properties. No direct antagonism was observable between strains that could dismiss their use as mixed cultures. L. plantarum CRL2162 and L. rhamnosus CRL2164 performed the best under pickling conditions with high growth and inhibitory activity against Escherichia coli and Listeria innocua, so they should be the most appropriate for inoculation and fermentation of vegetable foods. Further studies regarding their most suitable $L A B$ ratios and their application in vegetable pickle manufacturing at laboratory and pilot scale are presently ongoing. From an industrial point of view, the development of a new starter culture will allow for the obtaining of standardized fermented vegetable products of high quality, increasing the competitiveness of Argentinian production.

\section{ACKNOWLEDGEMENTS}

This work recived support by IC500 Project (2014-2016) of the University of San Pablo Tucuman and PIP 0319 from CONICET (Consejo Nacional de Investigaciones Científicas y Técnicas, Argentina).

\section{CONFLICTS OF INTEREST}

The authors declare no conflicts of interest.

\section{REFERENCES}

1. Van Hylckama Vlieg JET, Veiga P, Zhang C, Derrien M, Zhao L. Impact of microbial transformation of food on health From fermented foods to fermentation in the gastro-intestinal tract. Curr Opin Biotechnol. 2011;22(2):211-9. https://doi.org/10.1016/S0956-7135(96)00039-4

2. Zárate G, Perez Chaia A. Propionibacteria also have probiotic potential. In: Venema K, do Carmo AP, editors. Probiotics and prebiotics: Current research and future trends. Poole, UK: Caister Academic Press; 2015. pp. 69-92.

https://doi.org/10.21775/9781910190098.05

3. Raspor P, Goranovič D. Biotechnological applications of acetic acid bacteria. Crit Rev Biotechnol. 2008;28(2):101-24. https://doi.org/10.1080/07388550802046749

4. Yu J, Gao W, Qing M, Sun Z, Wang W, Liu W, et al. Identification and characterization of lactic acid bacteria isolated from traditional pickles in Sichuan, China. J Gen Appl Microbiol. 2012;58(3):163-72.

https://doi.org/10.2323/jgam.58.163

5. Savitri M, Kumar V, Kumari A, Angmo K, Bhalla TC. Isolation and characterization of lactic acid bacteria from traditional pickles of Himachal Pradesh, India. J Food Sci Technol. 2017; 54(7):1945-52 https://doi.org/10.1007/s13197-017-2629-1

6. Di Cagno R, Coda R, De Angelis M, Gobbetti M. Exploitation of vegetables and fruits through lactic acid fermentation. Food Microbiol. 2013;33(1):1-10.

https://doi.org/10.1016/j.fm.2012.09.003

7. Kandler O, Weiss N. Genus Lactobacillus Beijerinck 1901. In: Sneath PHA, Mair NS, Sharpe ME, Holt JG, editors. Bergey's manual of systematic bacteriology, Vol. II. Baltimore, MD, USA: Williams and Wilkins; 1986. pp.1209-34.

8. AACC Method 02-31.01. Titratable acidity. St. Paul, MN, USA: American Association of Cereal Chemists (AACC) International; 2000.

https://doi.org/10.1094/AACCIntMethod-02-31.01

9. Church FC, Swaisgood HE, Porter DH, Catignani GL. Spectrophotometric assay using o-phthaldialdehyde for determination of proteolysis in milk and isolated milk proteins. J Dairy Sci. 1983;66(6):1219-27.

https://doi.org/10.3168/jds.S0022-0302(83)81926-2

10. Thapa N, Pal J, Tamang JP. Phenotypic identification and technological properties of lactic acid bacteria isolated from traditionally processed fish products of the Eastern Himalayas. Int J Food Microbiol. 2006;107(1):33-8. https://doi.org/10.1016/j.jifoodmicro.2005.08.009

11. Medina RB, Katz M, Gonzalez S, Oliver G. Characterization of the lactic acid bacteria in ewe's milk and artisanal cheese from Northwest Argentina. J Food Prot. 2001;64(4):559-63. https://doi.org/10.4315/0362-028X-64.4.559 
12. Juárez Tomás MS, Bru de Labanda E, Ruiz Holgado AP, Nader-Macías ME. Estimation of vaginal probiotic lactobacilli growth parameters with the application of the Gompertz model. Can J Microbiol. 2002;48(1):82-92.

https://doi.org/10.1139/w01-135

13. Zwietering $\mathrm{MH}$, Jongenburger I, Rombouts FM, Van't Riet $\mathrm{K}$. Modeling of the Bacterial growth curve. Appl Environ Microbiol. 1990;56(6):1875-81.

14. Pospiech A, Neumann B. A versatile quick-prep of genomic DNA from Gram-positive bacteria. Trends Genet. 1995; 11(6):217-8.

https://doi.org/10.1016/S0168-9525(00)89052-6

15. Hébert EM, Raya RR, Tailliez P, Savoy de Giori G. Characterization of natural isolates of Lactobacillus strains to be used as starter cultures in dairy fermentation. Int J Food Microbiol. 2000;59(1-2):19-27.

https://doi.org/10.1016/S0168-1605(00)00282-8

16. Hagemann TL, Kwan SP. ABI sequencing analysis. Manipulation of sequence data from the ABI DNA sequencer. Mol Biotechnol. 1999;1:13(2):137-52.

https://doi.org/10.1385/MB:13:2:137

17. Madden T. The BLAST sequence analysis tool. In: McEntyre J, Ostell J, editors. The NCBI Handbook. Bethesda, MD, USA: National Center for Biotechnology Information; 2002. Available from: http://www.ncbi.nlm.nih.gov/ books/NBK21097/.

18. Cole JR, Wang Q, Cardenas E, Fish J, Chai B, Farris RJ, et al. The ribosomal database project: Improved alignments and new tools for rRNA analysis. Nucleic Acids Res. 2009; 37(1):D141-5.

https://doi.org/10.1093/nar/gkn879

19. Kulikova T, Aldebert P, Althorpe N, Baker W, Bates K, Browne $\mathrm{P}$, et al. The EMBL nucleotide sequence database. Nucleic Acids Res. 2004;32(Suppl_1):D27-30.

https://doi.org/10.1093/nar/gkh120

20. Osawa R, Kuroiso K, Goto S, Shimizu A. Isolation of tannin-degrading lactobacilli from humans and fermented foods. Appl Environ Microbiol. 2000;66(7):3093-7.

https://doi.org/10.1128/AEM.66.7.3093-3097.2000

21. Sáez GD, Hébert EM, Saavedra L, Zárate G. Molecular identification and technological characterization of lactic acid bacteria isolated from fermented kidney beans flours (Phaseolus vulgaris L. and P. coccineus) in northwestern Argentina. Food Res Int. 2017;102:605-15. https://doi.org/10.1016/j.foodres.2017.09.042

22. Chapman CMC, Gibson GR, Rowland I. In vitro evaluation of single- and multi-strain probiotics: Inter-species inhibition between probiotic strains, and inhibition of pathogens. Anaerobe. 2012;18(4):405-13.

https://doi.org/10.1016/j.anaerobe.2012.05.004

23. Minitab Statistical Software, v. 17, Minitab Inc., State College, PA, USA; 2014. Available from: https://www.minitab.com.
24. XLSTAT, v. 19.4, Data Analysis and Statistical Solution for Microsoft Excel, Addinsoft, NY, USA; 2017. Available from: https://www.xlstat.com.

25. TIBCO Statistica, v. 13.3.0, TIBCO Software Inc, Palo Alto, CA, USA; 2017. Available from: https://www.tibco.com/ products/tibco-statistica.

26. Saedi M, Shahidi F, Mortazavi SA, Milani E, Yazdi FT. Isolation and identification of lactic acid bacteria in winter salad (local pickle) during fermentation using 16S rRNA gene sequence analysis. J Food Safety. 2015;35(3):287-94. https://doi.org/10.1111/jfs.12128

27. Jampaphaeng K, Cocolin L, Maneerat S. Selection and evaluation of functional characteristics of autochthonous lactic acid bacteria isolated from traditional fermented stinky bean (sataw-dong). Ann Microbiol. 2016;67(1):2536.

https://doi.org/10.1007/s13213-016-1233-3

28. Çon $\mathrm{AH}$, Karasu N. Determination of antagonistic starter cultures for pickle and olive fermentation processes. Czech J Food Sci. 2009;27(3):185-93.

29. Verni M, Wang C, Montemurro M, De Angelis M, Katina K, Rizzello CG,Coda R. Exploring the microbiota of faba bean: Functional characterization of lactic acid bacteria. Front Microbiol. 2017;8:2461.

https://doi.org/10.3389/fmicb.2017.02461

30. Karasu N, Şimşek Ö, Çon AH. Technological and probiotic characteristics of Lactobacillus plantarum strains isolated from traditionally produced fermented vegetables. Ann Microbiol. 2010;60(2):227-34.

https://doi.org/10.1007/s13213-010-0031-6

31. Zago M, Lanza B, Rossetti L, Muzzalupo I, Carminati D, Giraffa $G$. Selection of Lactobacillus plantarum strains to use as starters in fermented table olives: Oleuropeinase activity and phage sensitivity. Food Microbiol. 2013;34(1):81-7. https://doi.org/10.1016/j.fm.2012.11.005

32. Beganović J, Kos B, Leboš Pavunc A, Uroić K, Jokić M, Šušković J. Traditionally produced sauerkraut as source of autochthonous functional starter cultures. Microbiol Res. 2014;169(7-8):623-32.

https://doi.org/10.1016/j.micres.2013.09.015

33. Douillard FP, Ribbera A, Kant R, Pietilä TE, Järvinen HM, Messing $M$, et al. Comparative genomic and functional analysis of 100 Lactobacillus rhamnosus strains and their comparison with strain GG. PLoS Genet. 2013;9(8): e1003683.

https://doi.org/10.1371/journal.pgen.1003683

34. Dos Santos KMO, Vieira ADS, Buriti FCA, Nascimento JCF, de Melo LM, Bruno M, et al. Artisanal coalho cheeses as source of beneficial Lactobacillus plantarum and Lactobacillus rhamnosus strains. Dairy Sci Technol. 2015;95(2): 209-30.

https://doi.org/10.1007/s13594-014-0201-6

35. Fessard A, Remize F. Why are Weissella spp. not used as commercial starter cultures for food fermentation? Fermentation. 2017;3(3):38.

https://doi.org/10.3390/fermentation3030038 
36. Muñoz R, de las Rivas B, López de Felipe F, Reverón I, Santamaría L, Esteban-Torres M, et al. Biotransformation of phenolics by Lactobacillus plantarum in fermented foods. In: Frías J, Martinez-Villaluenga C, Peñas E, editors. Fermented foods in health and disease prevention. Cambridge, MA, USA: Academic Press; 2017. pp. 63-83. https://doi.org/10.1016/B978-0-12-802309-9.00004-2

37. Rodríguez H, de las Rivas B, Gómez-Cordovés C, Muñoz R. Characteriztaion of tannase activity in cell-free extracts of Lactobacillus plantarum CECT 748. Int J Food Microbiol. 2008;121(1):92-8.

https://doi.org/10.1016/j.ijfoodmicro.2007.11.002

38. Curiel JA, Rodríguez H, Landete JM, de las Rivas B, Muñoz R. Ability of Lactobacillus brevis strains to degrade food phenolic acids. Food Chem. 2010;120(1):225-29. https://doi.org/10.1016/j.foodchem.2009.10.012

39. Goel G, Kumar A, Beniwal V, Raghav M, Puniya AK, Singh K. Degradation of tannic acid and purification and characterization of tannase from Enterococcus faecalis. Int Biodeterior Biodegradation. 2011;65(7):1061-5. https://doi.org/10.1016/j.ibiod.2011.08.006

40. Jiménez N, Barcenilla JM, de Felipe FL, de las Rivas B, Muñoz R. Characterization of a bacterial tannase from Streptococcus gallolyticus UCN34 suitable for tannin biodegradation. Appl Microbiol Biotechnol. 2014;98(14):6329-37. https://doi.org/10.1007/s00253-014-5603-0
41. Pla ML, Oltra S, Esteban MD, Andreu S, Palop A. Comparison of primary models to predict microbial growth by the plate count and absorbance methods. BioMed Res Int. 2015 (2015); Article ID 365025.

https://doi.org/10.1155/2015/365025

42. Pundir RK, Rana S, Kashyap N, Kaur A. Probiotic potential of lactic acid bacteria isolated from food samples - An in vitro study. J Appl Pharm Sci. 2013;3(3):85-93.

https://doi.org/10.7324/JAPS.2013.30317

43. Reis JA, Paula AT, Casarotti SN, Penna ALB. Lactic acid bacteria antimicrobial compounds: Characteristics and applications. Food Eng Rev. 2012;4(2):124-40.

https://doi.org/10.1007/s12393-012-9051-2

44. Rao Y, Chang W, Xiang W, Li M, Che Z, Tang J. Screening and performance of Lactobacillus plantarum E11 with bacteriocin-like substance secretion as fermentation starter of sichuan pickle. J Food Safety. 2013;33(4):445-52.

https://doi.org/10.1111/jfs.12075

45. Timmerman HM, Koning CJM, Mulder L, Rombouts FM, Beynen AC. Monostrain, multistrain and multispecies probiotics - A comparison of functionality and efficacy. Int J Food Microbiol. 2004;96(3):219-33.

https://doi.org/10.1016/j.ijfoodmicro.2004.05.012 